\title{
Ozone trends in the vertical structure of Upper Troposphere and Lower stratosphere over the Indian monsoon region
}

\author{
S. Fadnavis $\cdot$ S. Dhomse $\cdot$ S. Ghude $\cdot$ \\ U. Iyer $\cdot$ P. Buchunde $\cdot$ S. Sonbawne $\cdot$ \\ P. E. Raj
}

Received: 20 February 2012/Revised: 18 February 2013/Accepted: 11 March 2013/Published online: 4 April 2013

(C) Islamic Azad University (IAU) 2013

\begin{abstract}
Ozone trends in the Upper Troposphere and Lower Stratosphere over the Indian region are investigated using three satellite data sets namely Halogen Occultation Experiment (1993-2005), Stratospheric Aerosol and Gas Experiment (1993-2005) II, and Aura Microwave Limb Sounder (MLS, 2005-2011). Estimated ozone trends using multi-variate regression analysis are compared with trends at two Indian ozonesonde stations (Delhi, $28^{\circ} \mathrm{N}, 77^{\circ} \mathrm{E}$ and Pune, $18^{\circ} \mathrm{N}, 73^{\circ} \mathrm{E}$ ), and a 3 -D Chemical Transport Model (CTM, SLIMCAT) for the 1993-2005 time period. Overall, all the observational data sets and model simulations indicate significant increasing trend in the upper troposphere (0-2.5\%/year). In the lower stratosphere, estimated trends are slightly positive up to $30 \mathrm{mb}$ and are negative between 30 and $10 \mathrm{mb}$. Increasing trends in the upper troposphere is probably due to increasing trends in the tropospheric ozone precursor gases (e.g. $\mathrm{CO}, \mathrm{NO}_{x}$, NMHCs). Here, we argue that these contrasting ozonetrend profiles might be partially responsible for insignificant long-term trends in the tropical total column ozone. On seasonal scale, positive trends are observed during all the seasons in the upper troposphere while structure of trend profile varies in lower stratosphere. Seasonal variations of ozone trends and its linkages with stratospheric intrusions and increasing trends in lightning flashes in the troposphere are also discussed.
\end{abstract}

S. Fadnavis $(\varangle) \cdot$ S. Ghude $\cdot$ U. Iyer $\cdot$ P. Buchunde

S. Sonbawne - P. E. Raj

Indian Institute of Tropical Meteorology, Pune, India

e-mail: suvarnafadnavis@gmail.com

S. Dhomse

Institute for Climate and Atmospheric Science, School of Earth and Environment, University of Leeds, Leeds, UK
Keywords Ozone trends - Upper troposphere and lower stratosphere $\cdot$ Indian monsoon region

\section{Introduction}

Ozone $\left(\mathrm{O}_{3}\right)$ is an important trace gas in the troposphere. It plays important role in atmospheric chemistry, acts a greenhouse gas and contributes significantly to climate change. Ozone increase in troposphere due to anthropogenic precursor emissions has significantly contributed to changes in radiative forcing since preindustrial times $\left(\sim 0.35 \mathrm{~W} \mathrm{M}^{-2}\right.$, IPCC 2001) and can have significant impact on the surface temperature (Forster and Shine 1997; IPCC 2007). Concentrations of the upper tropospheric lower stratospheric (UTLS) ozone are controlled by various chemical and dynamical processes such as photochemical production within the troposphere, downward/upward transport from the stratosphere/troposphere through Stratosphere-Troposphere Exchange (STE) (Fadnavis et al. 2010), and deep convection (Randel et al. 2010; Fadnavis et al. 2011), and transport processes within the troposphere (Ghude et al. 2011). Changes in the UTLS ozone affect the temperature and dynamical structure of the UTLS. From observations and model simulations, it is well established that decrease (increase) in the UTLS ozone leads to local cooling (warming) (e.g., Forster et al. 2007; Braesicke et al. 2011).

Long-term trends in tropospheric and lower stratospheric ozone show a complex pattern over the globe and in some cases are driven by regional influences (Harris et al. 1997; Logan et al. 1999; Randel et al. 1999; Oltmans et al. 1998, 2004; Staehelin et al. 2001). There are few focused studies reporting ozone trends in the lower stratosphere over the tropical region. Using Stratospheric 
Aerosol and Gas Experiment (SAGE II) data (1984-2005) and Southern Hemisphere Additional Ozonesondes (SHADOZ) measurements (1998-2009) Randel and Thompson (2011) reported statistically significant negative trends $(0.2-0.4 \%$ per year) in the tropical lower stratosphere $(\sim 17-21 \mathrm{~km})$. Chemistry climate model simulations also show similar decreasing decadal ozone trends in the tropical lower stratosphere as a result of increase in tropical upwelling in the model through strengthening of the stratospheric meridional circulation (Eyring et al. 2010; Lamarque and Solomon 2010). Randel and Wu (2007) reported decreasing ozone trends in the tropics (larger than $-10 \%$ below $20 \mathrm{~km}$ ). The comparison of SAGE II trends with ozonesonde indicates that SAGE II ozone show relatively larger decrease in the tropical lower stratosphere. However, both satellite and ground-based stations show negligible trends in the tropical total column ozone (WMO 2010). Thus, observed contrasting ozone trend profiles might be partially responsible for insignificant long-term trends in the tropical total column ozone.

Studies on tropospheric ozone trends over the Indian region mostly addressed trends in tropospheric column ozone. Increasing trends in tropospheric ozone residual (TOR) measurements over the Indian inland cities are reported by Kulkarni et al. (2010). Ganguly (2009) also observed overall increasing ozone trends $(1.2-7 \%)$ over the Indian forests for the period 1980-2000. Using Ozone Mapping Instrument measurements Nishanth and Satheesh (2011) reported increasing ozone trends $\sim 8.8 \%$ year over the Indian coastal cities. From ozonesonde measurements, trends in the Indian troposphere and lower stratosphere were reported by Saraf and Beig (2004). These trends have been attributed to significant increase in anthropogenic emission of ozone precursors from South Asia during past couple of decades due to strong industrial and economic growth in this region (Beig et al. 2008; Lal and Pawar 2011; Kulkarni et al. 2010; Wang et al. 2012; Ghude et al. 2008; Krishnamurti et al. 2009). To our knowledge, ozone trends in the UTLS region are not well studied over the India where significant transport of air from surface to UTLS through deep convection (Randel et al. 2010) and STE occurs during monsoon season.

In this paper, we particularly concentrate on the trends in ozone concentration in the UTLS region over the Indian monsoon region $\left(0-30^{\circ} \mathrm{N}, 60-100^{\circ} \mathrm{E}\right)$. UTLS over Indian region has some unique features due to cross tropopause transport. For example, transport of boundary layer air into lower stratosphere due to strong Summer monsoon convection (Park et al. 2009; Goswami et al. 2006; Kunze et al. 2010; Randel et al. 2010; Chen et al. 2012). Stratospheric intrusion during Winter and early pre-monsoon season (Fadnavis et al. 2010) and cyclonic activity during premonsoon and post-monsoon seasons (Das et al. 2011;
Baray et al. 1999; Sigmond et al. 2000). Cross-tropopause transport changes the composition of the upper troposphere and lower stratosphere.

We use four observational data sets namely Halogen Occultation Experiment (HALOE), SAGE II for the period 1993-2005, Aura Microwave Limb Sounder (MLS) for the period $2005-2011$ over, Indian monsoon region $\left(0^{\circ}-30^{\circ} \mathrm{N}\right.$, $\left.60^{\circ}-100^{\circ} \mathrm{E}\right)$ and ozonesonde observations at two Indian stations Pune $\left(18^{\circ} \mathrm{N}, 73^{\circ} \mathrm{E}\right)$ and Delhi $\left(28^{\circ} \mathrm{N}, 77^{\circ} \mathrm{E}\right)$ for the period 1993-2005. The results obtained are compared with trends obtained from simulations of 3-D Chemical Transport Model (SLIMCAT). Further, the impact of cross tropopause transport on ozone trends is discussed.

This paper is organized as follows: In Sect. "Data and Analysis", data sets and regression model used are discussed. In Sect. "Results and Discussions", results on annual as well as seasonal trends are presented and discussed. Conclusions are given in Sect. "Conclusions".

\section{Data and analysis}

\section{SAGE II, HALOE, MLS satellite data}

This paper analyses ozone data from three satellite-based instruments namely Stratospheric Aerosol and Gas Experiment II (SAGE II) aboard the Earth Radiation Budget Satellite (ERBS), HALOE aboard the Upper Atmospheric Research Satellite (UARS), and AURA MLS aboard UARS.

The SAGE II data used here are based on the v6.2 retrieval algorithm. SAGE II is a solar occultation instrument where measurements are only made during limb viewing conditions providing 15 sunrise and 15 sunset measurements per day. Retrieved profiles are in number density at $<1 \mathrm{~km}$ resolution in height coordinate $(T(\mathrm{z}))$. Data are obtained from http://badc/sage2/data/version_6.2. SAGE II v6.2 data are screened for cloud and aerosol contamination according to the procedure described by Wang et al. (2002). Although SAGE II is not optimally designed for tropospheric monitoring, the four longer wavelength channels frequently sample into the troposphere (Wang et al. 1994, 1998). How deep the SAGE II instrument can measure into the troposphere depends on the altitude of cloud presence. The uncertainty of SAGE II ozone data increases rapidly below $20 \mathrm{~km}$ (Cunnold et al. 1989). Errors are estimated to be around $20 \%$ for measurement before the Pinatubo eruption in June 1991. Systematic biases toward higher values are also known for ozone in the 12-20 km range (Pan et al. 1997). The precision of SAGE II v 6.2 data is $\sim 10 \%$ at $20 \mathrm{~km}$ and $40 \%$ at $10 \mathrm{~km}$.

Halogen Occultation Experiment is also limb-viewing solar occultation instrument that obtains transmittance 
profiles in infra-red region of the spectrum giving 15 sunrise and 15 sunset measurements (Russell et al. 1993). HALOE was operational from September 1991 to November 2005. The vertical resolution is $\sim 2 \mathrm{~km}$ or less and retrieved data is in pressure coordinate $(T(\mathrm{p}))$. Temporal and spatial coverage of HALOE are similar to those of SAGE II (Terao and Logan 2007). Comparison of ozonesonde, HALOE, and SAGE II ozone profiles in UTLS region is reported elsewhere (Borchi and Pommereau 2007). In this study, we used the HALOE version 19 (V19, $T(\mathrm{p})$ ) ozone data obtained from http://haloethree.larc.nasa. gov/download/

In order to avoid the influence of Mount Pinatubo eruption HALOE and SAGE II data are analyzed for the period 1993-2005.

The Aura MLS measurements are obtained from observations of millimetre-wavelength thermal emission as the instrument field of view is vertically scanned through the atmospheric limb. An overview of the MLS spectral bands, main line frequencies, and target molecules, are reported by Waters et al. (2006). The overall MLS retrieval approach is discussed by Livesey et al. (2006). Froidevaux et al. (2008) have shown that the radiance fits are generally very good (within $\sim 1 \%$ ) although there is typically poorer closure in the lowermost height region (upper troposphere). The MLS v3 ozone data is obtained from http://mirador.gsfc.nasa.gov. In order to have large number of data points so that random error in HALOE and SAGE II, MLS data is reduced we estimated trends over wider area of complete Indian region $\left(0-30^{\circ} \mathrm{N}, 60-100^{\circ} \mathrm{E}\right)$. The monthly mean HALOE, SAGE II, and MLS data are averaged over the Indian region. In general, there are 8-15 data points for a month over this region. The months in which available data points are $<8$ are not taken into consideration. Although there are similarities in the observations made by HALOE and SAGE II instruments, analyzed results may differ because of many reasons. Their spatial coverage may differ over the selected latitudinal belt (e.g., for a month, HALOE may view $10-25^{\circ} \mathrm{S}$ and SAGE may view $12-30^{\circ} \mathrm{S}$ ). Also SAGE II is seven-channel photometer with photo-diode detector whereas HALOE uses broadband and gas-correlation radiometry. Hence, they have different retrieval algorithms and hence different retrieval errors. Moreover, each instrument makes measurements at different periods in a month, which may give rise to sampling uncertainty.

\section{Ozonesonde data}

The ozonesonde measures the vertical distribution of ozone from surface to the lower stratosphere. In general, weekly ozone soundings are made using modified electrochemical Bewer Bubbler ozone sensor (B-M Sonde) (Shreedharan
1968). The ozone profile ( $\mu \mathrm{mb})$ after integrating vertically has been normalized to the total ozone measured by Dobson spectrophotometer. The performance of the electrochemical concentration cell and the Indian ozonesonde were assessed in several inter comparisons (WMO 1994; Smit et al. 1996) and it was concluded that the precision of a measurement at the ozone layer peak is better than $\pm 2 \%$ (WMO 1994). In the present study, we use ozone time series which are extended time series reported by Saraf and Beig (2004). The ozonesonde data obtained during the period 1993-2005 over three Indian stations Pune $\left(18^{\circ} \mathrm{N}\right.$, $\left.73^{\circ} \mathrm{E}\right)$, Delhi $\left(28^{\circ} \mathrm{N}, 77^{\circ} \mathrm{E}\right)$, and Trivandrum $\left(28^{\circ} \mathrm{N}, 77^{\circ} \mathrm{E}\right)$ are used in the current analysis. On an average, there are 2-6 soundings per month. Data are sparse over Trivandrum during the period of analysis (1993-2005), hence analysis is not presented at this station. Saraf and Beig (2004) also reported statistically insignificant ozone trends at Trivandrum throughout the troposphere.

\section{Chemical transport model (SLIMCAT) set up}

Single Layer Isentropic Model of Chemistry and Transport (SLIMCAT) is a 3-D chemical transport model, which uses sigma coordinate system and extends from surface to $\sim 60 \mathrm{~km}$. Detailed description of the model is given in Chipperfield (1999) and latest updates in Chipperfield (2006). Model is forced with European Centre for Medium Range Weather Forecasting reanalysis data (ERA-Int, Dee et al. 2011) for 1992-2000. Model dynamical fields are updated with ERA-Int data every $6 \mathrm{~h}$ (00, 06, 12, and 18 UTC). In present study, model simulations are performed at T21L32 (32 vertical levels and $5.6 \times 5.6^{\circ}$ horizontal) resolution, Model has detailed stratospheric chemistry scheme, including heterogeneous chemistry. Data presented here is similar to run B_EI from Dhomse et al. (2011).

Thus, the present work analyzes observations from SAGE II (January 1993-August 2005), HALOE (January 1993-November 2005), MLS (January 2005-September $2011)$ over the Indian monsoon region $\left(0-30^{\circ} \mathrm{N}\right.$, $\left.60-100^{\circ} \mathrm{E}\right)$, ozonesonde measurements at Pune and Delhi (January 1993-December 2005) and SLIMCAT simulations (January 1993-December 2005). Trend estimates are calculated for the Upper Troposphere and Lower stratospheric (UTLS) pressure levels 200-10 mb-i.e., an approximate altitude range $10-32 \mathrm{~km}$. Data are considered from 1993 to avoid the influence of Mt Pinatubo eruption in June 1991. In most of the months there are about 15-20 observations available in the satellite data sets. However there are few months when observations are not available in the satellite data sets. The time series of all the data sets are de-seasonalized by removing the respective long-term monthly means, and in all of the analysis below we focus on deseasonalized anomalies. 
Regression analysis

To calculate long-term ozone trends, it is necessary to remove the influence of various short- and long-term physical process such as quasi-biennial oscillation (QBO), El Niño-Southern Oscillation (ENSO), and 11-year solar cycle (Fadnavis and Beig 2006a; Dhomse et al. 2006; WMO 2010). We use a regression model which is an extended version of the model of Randel and Cobb (1994) in the current analysis. The general expression for the regression model equation can be written as follows:

$$
\begin{aligned}
\theta(t, z)= & \alpha(z)+\beta(z) . \text { Trend }(t)+\gamma(z) \cdot \mathrm{QBO}(t) \\
& +\delta(z) . \text { Solar }(t)+\varepsilon(z) . \operatorname{ENSO}(t)+\operatorname{resid}(t)
\end{aligned}
$$

Model uses harmonic expansion to calculate the coefficients $\alpha \beta \gamma \delta$, and $\varepsilon$ The harmonic expansion for $\alpha(t)$ is given as:

$$
\begin{aligned}
\alpha(t)= & A_{0}+A_{1} \cos \omega \mathrm{t}+A_{2} \sin \omega \mathrm{t}+A_{3} \cos 2 \omega \mathrm{t} \\
& +A_{4} \sin 2 \omega \mathrm{t}+A_{5} \cos 3 \omega \mathrm{t}+A_{6} \sin 3 \omega \mathrm{t} \\
& +A_{7} \cos 4 \omega \mathrm{t}+A_{8} \sin 4 \omega \mathrm{t}
\end{aligned}
$$

where $\omega=2 \pi / 12 ; A_{0}, A_{1}, A_{2}, \ldots$ are constants and $t(t=1$, $2, \ldots, n)$ is the time index $\alpha, \beta, \gamma, \delta$, and $\varepsilon$ are calculated at every altitude hence they are altitude (or pressure) dependent in Eq. 1. For a particular altitude (pressure level), these are calculated for every month and hence are timedependant in Eq. 2.

As a QBO proxy, $\mathrm{QBO}(t)$, we use Singapore monthly mean zonal winds $(\mathrm{m} / \mathrm{s})$ at $30 \mathrm{mbar}$ and the Southern Oscillation Index (SOI), which is the Tahiti $\left(18^{\circ} \mathrm{S}, 150^{\circ} \mathrm{W}\right)$ minus Darwin $\left(13^{\circ} \mathrm{S}, 131^{\circ} \mathrm{E}\right)$ monthly-mean sea-level pressures $(\mathrm{mb})$ as $\mathrm{ENSO}$ proxy, $\operatorname{ENSO}(t)$. QBO and $\mathrm{ENSO}$ indices are obtained from http://www.cpc.ncep.noaa.gov/ data/indice The F10.7 indices [Ottawa monthly-mean F10.7 solar radio flux as solar proxy (solar $(t)]$, are used here (http://spidr.ngdc.noaa.gov/spid). The terms $\alpha(z), \beta(z)$, $\gamma(z), \delta(z)$, and $\varepsilon(z)$ represent the time-dependent seasonal, trend, QBO, solar flux, and ENSO coefficients, respectively, and $\operatorname{resid}(t)$ represents the residues or noise. The model performs multiple regression analyses of time series at each given pressure level. Error estimates are according to Neter et al. (1985), which can be represented by the following expression:

$$
\begin{aligned}
\sigma^{2}(\alpha)=[ & \sigma^{2}\left(A_{0}\right)+\sigma^{2}\left(A_{1}\right) \cos ^{2} \omega t+\sigma^{2}\left(A_{2}\right) \sin ^{2} \omega t+\ldots \ldots \\
& +2\left(\sigma\left(A_{1}, A_{2}\right) \cos \omega t+\left(\sigma\left(A_{1}, A_{3}\right) \sin \omega t+\ldots \ldots\right)\right]
\end{aligned}
$$

Here, $\omega=2 \pi / 12, \sigma^{2}\left(A_{0}\right)$, and $\sigma\left(A_{1}, A_{2}\right)$, etc. are variance-covariance estimates of regression coefficients, obtained from least squares analysis (Randel and Cobb 1994).
Figure 1a exhibits the ozone time series at $200 \mathrm{mb}$ observed by HALOE instrument. Time series of residues obtained after regression analysis is shown in Fig. 1b. It indicates that residues are free from trend and other natural periodic signals. Figure 1c shows the time series of trend fit $\beta(z)$, which is a linear coefficient whose value is representative of the product of monthly trend value and linearly varying component. It is evident from Fig. 1c that there is a monotonic increase in ozone during the analysis period. The fluctuations in this figure represent the seasonal variability. A least square fit to this time series provide ozone trend in a given time series. The trend coefficients for each month (January, February,..., December) are averaged over all years. These monthly mean trend coefficients are averaged for different seasons to get seasonal trends. Annual trends are estimated by averaging monthly mean trend coefficient for of all the months at selected pressure level.

Figure $2 \mathrm{a}$ and $\mathrm{b}$ exhibit time series (red line with asterisks) and regression fit (black line) plot of ozone data at 200 and $50 \mathrm{mb}$ as obtained from ozonesonde at Delhi and Pune, SAGE II, HALOE, MLS, and SLIMCAT over the Indian region, respectively. Ozone anomalies in regression fit are obtained by subtracting residues from ozone time series. There are no apparent jumps in regression fit confirming the consistency of the data sets. For all the data sets and all the altitudes, residuals do not show any significant auto-correlation, while regression coefficients are highly correlated with observations. The correlation coefficient between regression coefficients and observations are varying between $\sim 0.5$ and $\sim 0.96$.

In the discussion that follows, we group the results by seasons: Winter (December-February), pre-monsoon (March-May), monsoon (June-September), and postmonsoon (October-November) and by pressure levels 200-100 mb $(\sim 10-18 \mathrm{~km})$ as upper troposphere and 100-10 $\mathrm{mb}(\sim 18-32 \mathrm{~km})$ as the lower stratosphere.

\section{Results and discussions}

Vertical structure of annual trends in ozone

The vertical distribution of annual mean ozone trend derived from HALOE, SAGE II, MLS, and ozonesonde (Delhi and Pune) measurements and SLIMCAT model simulation along with two sigma error limits are shown in Fig. 3 (trends at standard pressure levels are tabulated in Table 1). In general, all the data sets show statistically significant (at two sigma error limit) increasing trends varying between 0.5 and $2.3 \%$ /year in the upper troposphere. Trends obtained from SAGE II, HALOE, and SLIMCAT ozone vary between 1.2 and $2.3 \%$ /year between pressure levels $\sim 200-100 \mathrm{mb}$. In general, ozone 
Fig. 1 a Time series plot of ozone vmr as obtained from HALOE at $200 \mathrm{mb}$. b Residue plot of monthly mean ozone vmr as estimated from regression model after applying to HALOE time series at $200 \mathrm{mb}$. c Trend fit plot $\beta(z)$ of ozone time series obtained from HALOE at $200 \mathrm{mb}$. The $\mathrm{B}$-spline fit on the data points is shown by red line. The blue line indicates least square fit. Slop of blue line indicates trend coefficient
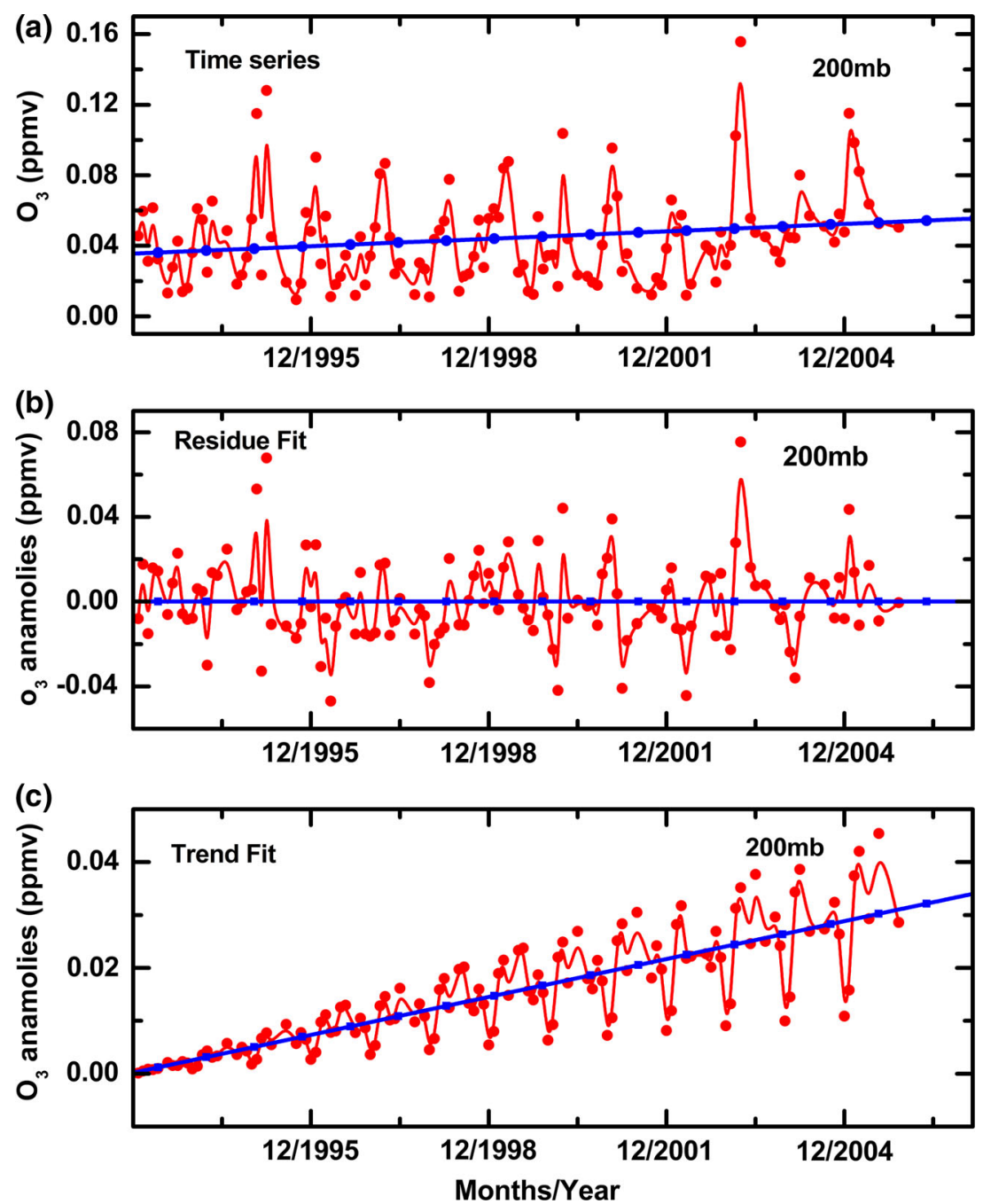

trends obtained from HALOE and SAGE II data agrees with those in SLIMCAT simulations. The trends profiles differ slightly but they lie within two-sigma limits of each other. Ozone trends obtained from MLS data vary between $0.5 \pm 0.8$ and $1.1 \pm 0.9 \%$ /year. At these pressure levels, ozone trends obtained from ozonesonde measurements at Delhi and Pune are less than the trends derived from SAGE II, HALOE measurements and SLIMCAT simulations. Ozone trends at Delhi vary between $-0.45 \pm 0.8$ and $1.3 \pm 0.65 \% / y e a r$ while at Pune it varies between $-0.45 \pm 0.5$ and $0.78 \pm 0.8 \%$ /year. From the ozonesonde measurements for the period 1992-2001, Saraf and Beig (2004) reported trend of $0.3 \pm 2.9 \%$ /year at Pune and $6.6 \pm 6.3 \%$ /year at Delhi near $200 \mathrm{mb}$. Trends estimated in the present study near $200 \mathrm{mb}$ are $0.67 \pm 0.8 \%$ /year at Pune and $1.3 \pm 0.65 \% / y e a r$ at Delhi. Trends reported by Saraf and Beig (2004) at Pune agrees with the present study while trends at Delhi are much higher (statistically insignificant) than in the present study.

In the lower stratosphere, at the altitudes above $100 \mathrm{mb}$ vertical profiles of trends obtained from SAGE II and
HALOE, MLS and SLIMCAT simulations show good agreement with each other. At the altitudes above $100 \mathrm{mb}$ trend values decrease with increase in altitude and no trends (zero trends) are observed near $30 \mathrm{mb}$. Increasing trends (0.2-1.1\%/year) although statistically insignificant are observed between 80 and $40 \mathrm{mb}$ pressure levels. HALOE, SAGE II, MLS data show decreasing trends at the altitudes above $30 \mathrm{mb}$ while SLIMCAT simulation shows decreasing trends near 15-10 mb. Statistically significant decreasing trends $\sim-0.3 \%$ year are observed (in SAGE II and HALOE) near $10 \mathrm{mb}$. Similar ozone trends are also reported by Fadnavis and Beig (2006b) over the tropical belt $0-30^{\circ} \mathrm{N}$. Throughout the lower stratosphere ozonesonde measurements at Pune show decreasing (statistically insignificant) trends ( $\sim 0.5 \% /$ year $)$. At Delhi derived trends are increasing $\sim 1 \pm 0.5 \% /$ year between 100 and $70 \mathrm{mb}$ and are decreasing ( $\sim-0.5 \% /$ year $)$ at the altitudes above $40 \mathrm{mb}$.

Trends obtained from SAGE II, HALOE, MLS measurements, and SLIMCAT simulations show agreement throughout the UTLS. Some differences in their vertical profile may be due to the fact that satellite instruments have 


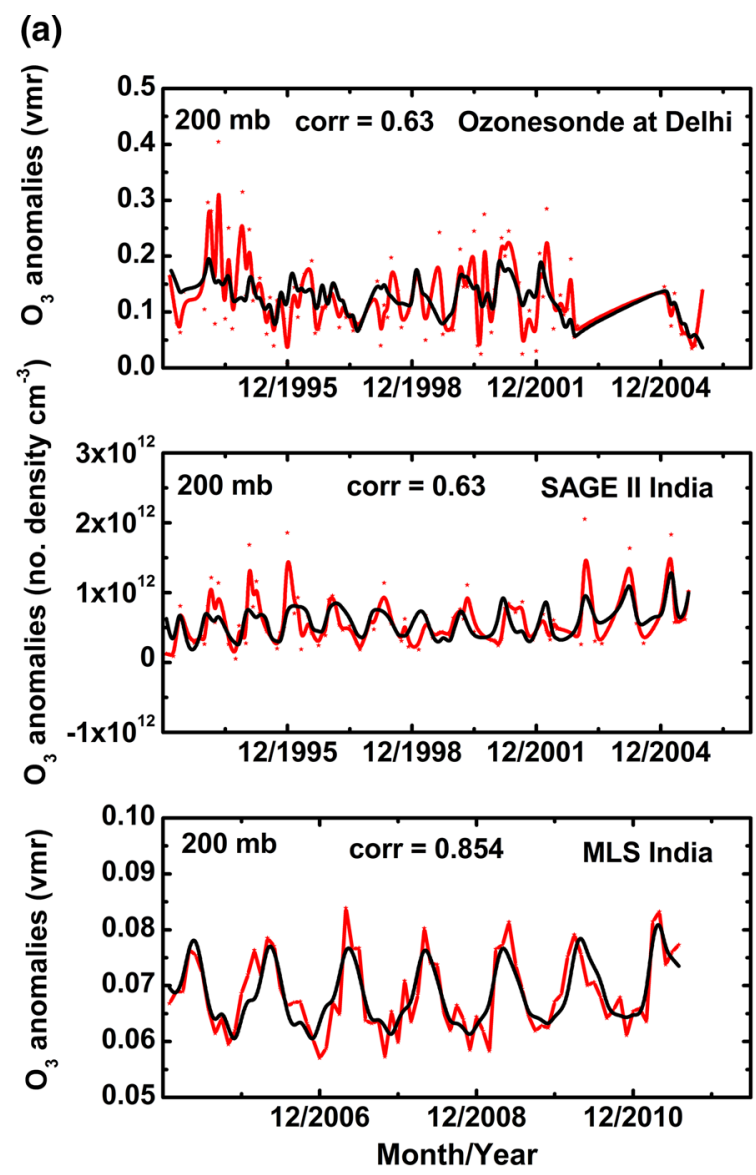

Fig. 2 a Time series (red line with asterisk) and regression fit (black line) plot of ozone data at $200 \mathrm{mb}$ as obtained from ozonesonde at Delhi and Pune, SAGE II, HALOE, MLS and SLIMCAT over the Indian region, respectively. Source of data and Correlation coefficient is indicated in each panel. b Time series (red line with asterisk) and

very different sampling patterns and sampling time (Fadnavis and Beig 2006b). Vertical profile of trends obtained from ozonesonde differ from trends profiles of SAGE II, HALOE, MLS measurements, and SLIMCAT simulations. This may be due to fact that SAGE II, HALOE MLS data and SLIMCAT simulations are over the Indian region while ozonesonde measurements at single station.

Seasonal trends in ozone over the UTLS region of India

Vertical structure of trends in ozone during winter season

To understand seasonality in the vertical distributions of trends, monthly mean trend coefficients are averaged for the four seasons mentioned above. Figure 4 shows vertical distribution of trends obtained from SAGE II, HALOE, MLS, ozonesonde measurements and SLIMCAT simulations during Winter season (Trend estimates at standard pressure levels are tabulated in Table 2). During Winter, in the upper troposphere, estimated trends are increasing trends in all the
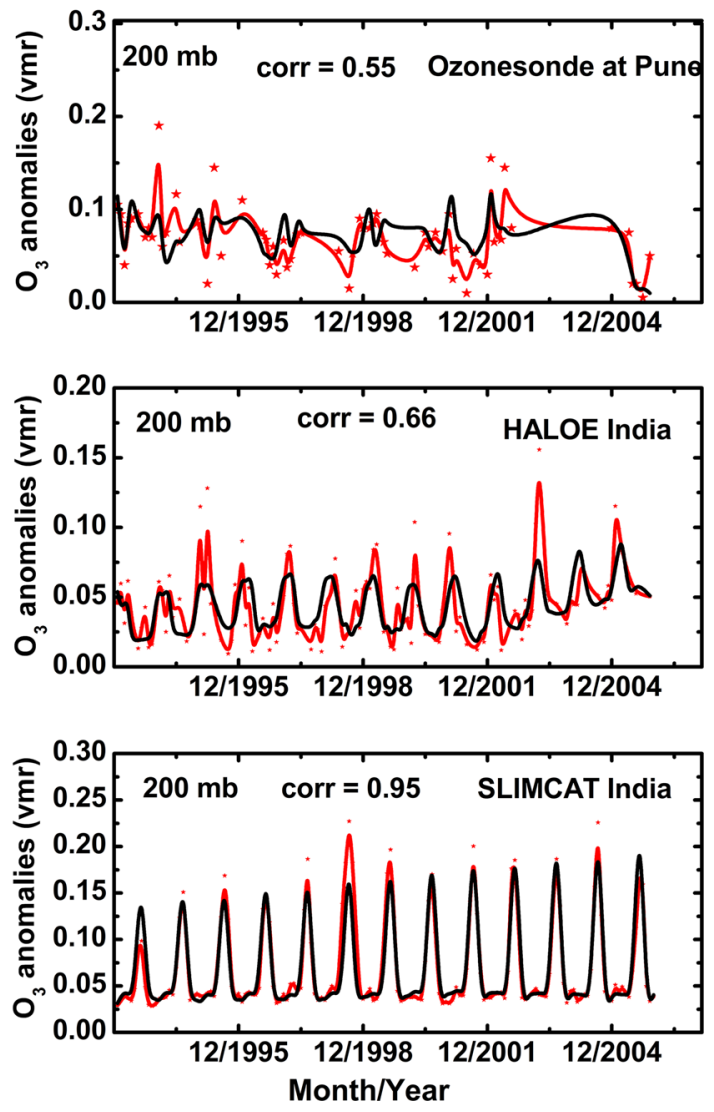

regression fit (black line) plot of ozone data at $50 \mathrm{mb}$ as obtained from ozonesonde at Delhi and Pune, SAGE II, HALOE, MLS and SLIMCAT over the Indian region, respectively. Source of data and Correlation coefficient is indicated in each panel

data sets. Statistically significant increasing trends are observed in SAGE II $(\sim 1.5 \pm 1.0-2.2 \pm 1.98 \%$ /year $)$ HALOE $(1.37 \pm 1.03-3.2 \pm 1.1 \% /$ year $)$, MLS $(0.9 \pm$ $0.8-1.87 \pm 1.2 \%$ /year) measurements and SLIMCAT $(1.5 \pm 1.0-3.48 \pm 2 \% / y e a r)$ simulations. Trends in ozonesonde measurements at Delhi vary between $0.98 \pm 0.6$ and $1.58 \pm 0.73 \%$ /year. Similar trends $(\sim 0.56 \pm 0.48 \% /$ year) are also reported by Kulkarni et al. (2010) at Delhi using tropospheric column ozone TOR data for the period 1979-2005. Observed trends in ozone at Pune station are statistically insignificant throughout the upper troposphere.

The source of ozone in the upper troposphere (during Winter-pre-monsoon season) is from stratospheric intrusions. Thus, observed Winter time increasing ozone trends in the upper troposphere may be due to stratospheric intrusions. Long-term trend obtained from HALOE measurements at different vertical level show maximum $(\sim 3.26 \pm 1.1 \%$ / year) near tropopause level. SAGE II, MLS, ozonesonde measurements (at Delhi), and SLIMCAT simulations also show maximum trend near tropopause level, which may be 
(b)


Fig. 2 continued

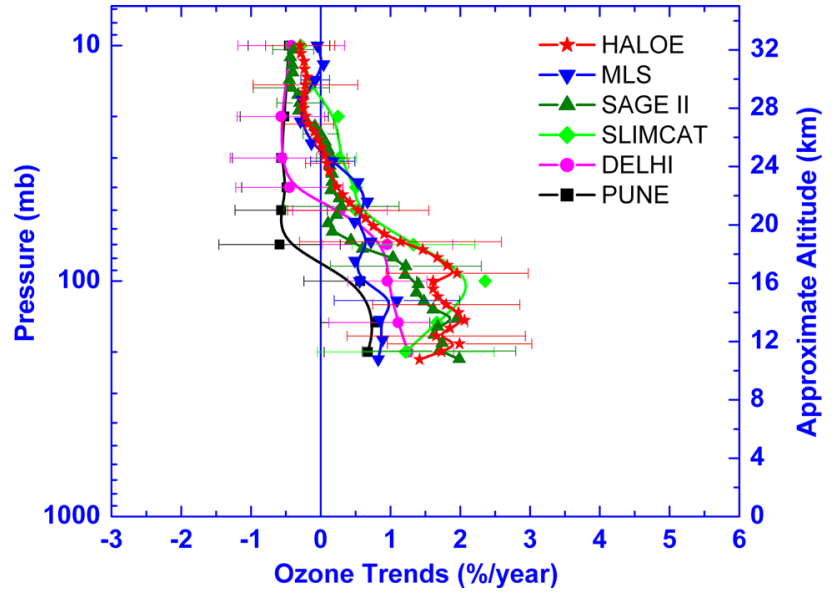

Fig. 3 Vertical variation of annual trends (\%/year) in ozone obtained from HALOE (asterisks), SAGE II (triangles), ozonesonde at Delhi (circles), ozonesonde at Pune (squares), MLS (down triangles), SLIMCAT (diamonds)

related to Winter time stratospheric intrusions. Figures $5 \mathrm{a}$ and b exhibit vertical distribution of area averaged (over the Indian region) monthly mean ozone mixing ratios obtained from
HALOE for the period 1993-2005 and MLS for the period 2005-2011, respectively. Dotted line over laid in the figure indicates variation of tropopause pressure (obtained from NCEP/NCAR reanalysis data). It can be seen from these figures that every Winter and early pre-monsoon seasons there is downward propagation of ozone crossing tropopause and entering in the upper troposphere. This may be related to stratospheric intrusions. From satellite observation and model simulations, Fadnavis et al. (2010) have shown that stratospheric intrusion occurs over the Indian subtropical region $\left(25-40^{\circ} \mathrm{N}\right)$ during Winter and early pre-monsoon seasons (February-March-April). Pune $\left(18^{\circ} \mathrm{N}, 73^{\circ} \mathrm{E}\right)$ being deep tropical station stratospheric intrusions may be weak or negligible over this region. Hence, increasing ozone trends near tropopause are not noticeable in ozonesonde data at Pune.

In the lower stratosphere, trends profiles obtained from SAGE II, HALOE MLS measurements and SLIMCAT simulations show decrease in trend value with increase in altitude. Increasing trends are observed between 100 and $30 \mathrm{mb}$ pressure levels. No trend (zero trend) is observed near $30 \mathrm{mb}$. Decreasing (although statistically insignificant) trends are observed between 20 and $10 \mathrm{mb}$. Similar variation of Winter 
Table 1 Annual trend coefficient (\%/year) over the Indian region in ozone measurements from SAGEII 1993-2005), HALOE (1993-2005), MLS (2005-2011), CTM-SLIMCAT (1993-2005),
Ozonesonde at Pune $\left(18^{\circ} \mathrm{N}, 73^{\circ} \mathrm{E}\right)(1993-2005)$, ozonesonde at Delhi $\left(28^{\circ} \mathrm{N}, 7^{\circ} \mathrm{E}\right)(1993-2005)$

\begin{tabular}{lllllll}
\hline $\begin{array}{l}\text { Pressure } \\
(\mathrm{hPa})\end{array}$ & $\begin{array}{l}\text { Trend (\%/year) } \\
\text { SAGEII } \\
(1993-2005)\end{array}$ & $\begin{array}{l}\text { Trend (\%/year) } \\
\text { HALOE } \\
(1993-2005)\end{array}$ & $\begin{array}{l}\text { Trend }(\% / y e a r) \\
\text { MLS } \\
(2005-2011)\end{array}$ & $\begin{array}{l}\text { Trend (\%/year) } \\
\text { SLIMCAT } \\
(1993-2005)\end{array}$ & $\begin{array}{l}\text { Trend (\%/year) } \\
\text { ozonesonde-Delhi } \\
\left(28^{\circ} \mathrm{N}, 77^{\circ} \mathrm{E}\right) \\
(1993-2005)\end{array}$ & $\begin{array}{l}\text { Trend }(\% / y e a r) \\
\text { ozonesonde-Pune } \\
\left(18^{\circ} \mathrm{N}, 73^{\circ} \mathrm{E}\right) \\
(1993-2005)\end{array}$ \\
\hline 200 & $1.7 \pm 1$ & $1.4 \pm 1.1$ & $0.82 \pm 0.3$ & $1.21 \pm 1.26$ & $1.3 \pm 0.65$ & $0.67 \pm 0.8$ \\
150 & $1.6 \pm 0.9$ & $2.06 \pm 1.05$ & $0.84 \pm 0.46$ & $1.66 \pm 1.5$ & $1.11 \pm 0.99$ & $0.78 \pm 0.8$ \\
100 & $1.3 \pm 1.1$ & $1.6 \pm 1.01$ & $0.55 \pm 0.31$ & $2.35 \pm 1.3$ & $0.95 \pm 0.56$ & $0.56 \pm 0.8$ \\
70 & $0.6 \pm 0.65$ & $1.14 \pm 1.4$ & $0.72 \pm 0.84$ & $1.32 \pm 0.8$ & $0.95 \pm 0.93$ & $-0.59 \pm 0.86$ \\
50 & $0.2 \pm 0.3$ & $0.53 \pm 1$ & $0.64 \pm 0.8$ & $0.50 \pm 0.43$ & $0.27 \pm 0.67$ & $-0.56 \pm 0.66$ \\
40 & $0.14 \pm 0.18$ & $0.2 \pm 0.31$ & $0.5 \pm 0.8$ & $0.50 \pm 0.4$ & $-0.45 \pm 0.8$ & $-0.48 \pm 0.64$ \\
30 & $0.15 \pm 0.2$ & $0.05 \pm 0.28$ & $0.17 \pm 0.31$ & $0.26 \pm 0.28$ & $-0.55 \pm 0.74$ & $-0.56 \pm 0.7$ \\
20 & $-0.22 \pm 0.21$ & $-0.21 \pm 0.3$ & $-0.29 \pm 0.32$ & $0.24 \pm 0.44$ & $-0.57 \pm 0.62$ & $-0.52 \pm 0.63$ \\
10 & $-0.33 \pm 0.29$ & $-0.29 \pm 0.5$ & $-0.04 \pm 0.2$ & $-0.28 \pm 0.21$ & $-0.42 \pm 0.76$ & $-0.45 \pm 0.58$ \\
\hline
\end{tabular}



Fig. 4 Vertical variation of trends (\%/year) in ozone during Winter season in ozone obtained from HALOE (asterisks), SAGE II (triangles), ozonesonde at Delhi (circles), ozonesonde at Pune (squares), MLS (down triangles), SLIMCAT (diamonds)

time ozone trends in lower stratosphere has been reported by Fadnavis and Beig (2006b) over the tropical belt (0-30 N). They reported decreasing ozone trends $\sim 0.8 \%$ /year between 20 and $10 \mathrm{mb}$ which agrees with present results. At Delhi in the region between 100 and $60 \mathrm{mb}$ statistically significant increasing ozone trends are observed. At the altitudes above $50 \mathrm{mb}$ statistically insignificant but decreasing ozone trends are observed. Ozone trends at Pune show decreasing ozone trends throughout the lower stratosphere.

\section{Vertical structure of trends in ozone during pre-monsoon season}

Figure 6 exhibits the vertical distribution of trends (SAGE II, HALOE, MLS, ozonesonde measurements, and
SLIMCAT simulations) during pre-monsoon season (Trend values at standard pressure levels are tabulated in Table 3). In the upper troposphere, trends obtained from SAGE II and HALOE measurements show excellent agreement. Estimated trends vary between 2 and $4 \%$ /year. Ozone trends obtained from MLS and ozonesonde data at Delhi and Pune vary between 0.5 and $1.4 \%$ /year. Trends profiles of MLS and ozonesonde data at Delhi and Pune lie within error bar of each other. From tropospheric column ozone TOR data Kulkarni et al. (2010) reported statistically insignificant but positive trends $\sim 0.04 \pm 0.3 \%$ /year at Delhi during premonsoon season. Trends derived from SLIMCAT simulations are decreasing (statistically insignificant) between 200 and $150 \mathrm{mb}$ levels. At the altitudes above $150 \mathrm{mb}$ ozone trends obtained from SLIMCAT simulations are increasing.

The observed increasing trends during pre-monsoon season may be due to transport of ozone precursors emitted from biomass burning (Galanter et al. 2000) and from thermal power plants, steel plants and cement plants which are well distributed over the Indian landmass enhances ozone levels in the planetary boundary layer throughout the year. During the pre-monsoon season, convection lifts the boundary layer pollutant along with ozone precursors and aerosols to the upper troposphere (Fadnavis et al. 2011; Phadnis et al. 2002). Several studies (Das 2009; Baray et al. 1999; Sigmond et al. 2000 and references therein) suggest that stratospheric ozone inputs to the troposphere can occur in the tropics near zones of deep convection. Also during pre-monsoon lightning during thunderstorms produces $\mathrm{NO}_{x}$. Recently, Lal and Pawar (2011) reported increasing trend of lighting activity during pre-monsoon season over the Indian inland stations. Increasing trends in lightning flashes will contribute to increasing ozone trends (via $\mathrm{NO}_{x}$ ) in the upper troposphere. Ghude et al. (2008) reported increasing trends in $\mathrm{NO}_{x}$ concentrations in the troposphere 
Table 2 Trend coefficient (\%/year) during Winter season over the Indian region in ozone measurements from SAGEII 1993-2005), HALOE (1993-2005), MLS (2005-2011), CTM-SLIMCAT

\begin{tabular}{lllllll}
$\begin{array}{l}\text { Pressure } \\
(\mathrm{hPa})\end{array}$ & $\begin{array}{l}\text { Trend (\%/year) } \\
\text { SAGEII } \\
(1993-2005)\end{array}$ & $\begin{array}{l}\text { Trend (\%/year) } \\
\text { HALOE } \\
(1993-2005)\end{array}$ & $\begin{array}{l}\text { Trend }(\% / y e a r) \\
\text { MLS } \\
(2005-2011)\end{array}$ & $\begin{array}{l}\text { Trend (\%/year) } \\
\text { SLIMCAT } \\
(1993-2005) \\
\text { Winter }\end{array}$ & $\begin{array}{l}\text { Trend (\%/year) } \\
\text { ozonesonde-Delhi } \\
\left(28^{\circ} \mathrm{N}, 77^{\circ} \mathrm{E}\right) \\
(1993-2005) \text { Winter }\end{array}$ & $\begin{array}{l}\text { Trend }(\% / y e a r) \\
\text { ozonesonde-Pune } \\
\left(18^{\circ} \mathrm{N}, 73^{\circ} \mathrm{E}\right) \\
(1993-2005)\end{array}$ \\
\hline 200 & Winter & $1.37 \pm 1.03$ & $0.91 \pm 0.9$ & $1.49 \pm 1.2$ & $0.98 \pm 0.66$ & $0.42 \pm 0.32$ \\
150 & $1.58 \pm 1$ & $2.2 \pm 1.3$ & $0.95 \pm 0.7$ & $2 \pm 1.5$ & $1.08 \pm 0.88$ & $0.67 \pm 0.65$ \\
100 & $2.2 \pm 1.98$ & $3.26 \pm 1.1$ & $1.87 \pm 1.2$ & $3.48 \pm 2$ & $1.58 \pm 0.73$ & $0.42 \pm 0.92$ \\
70 & $1.4 \pm 1.1$ & $2.04 \pm 1.04$ & $0.93 \pm 0.8$ & $1.56 \pm 1$ & $0.6 \pm 0.5$ & $-0.63 \pm 0.51$ \\
50 & $1.7 \pm 1.03$ & $0.69 \pm 0.95$ & $0.96 \pm 0.9$ & $0.77 \pm 0.6$ & $-0.4 \pm 0.21$ & $-0.6 \pm 0.53$ \\
40 & $0.91 \pm 0.78$ & $0.35 \pm 0.5$ & $1.03 \pm 0.8$ & $0.77 \pm 0.5$ & $-0.34 \pm 0.49$ & $-0.4 \pm 0.57$ \\
30 & $0.03 \pm 0.3$ & $0.02 \pm 0.3$ & $0.35 \pm 0.25$ & $0.25 \pm 0.35$ & $-0.3 \pm 0.56$ & $-0.3 \pm 0.43$ \\
20 & $-0.4 \pm 0.3$ & $-0.42 \pm 0.5$ & $-0.37 \pm 0.3$ & $0.14 \pm 0.3$ & $-0.2 \pm 0.3$ & $-0.2 \pm 0.37$ \\
10 & $0.15 \pm 0.16$ & $-0.61 \pm 0.7$ & $-0.39 \pm 0.4$ & $-0.36 \pm 0.29$ & $-0.15 \pm 0.2$ & $-0.1 \pm 0.3$ \\
\hline
\end{tabular}

(1993-2005), Ozonesonde at Pune $\left(18^{\circ} \mathrm{N}, 7^{\circ} \mathrm{E}\right)(1993-2005)$, ozonesonde at Delhi $\left(28^{\circ} \mathrm{N}, 7^{\circ} \mathrm{E}\right)(1993-2005)$ (a) Seasonal variation of HALOE ozone in UTLS (India)
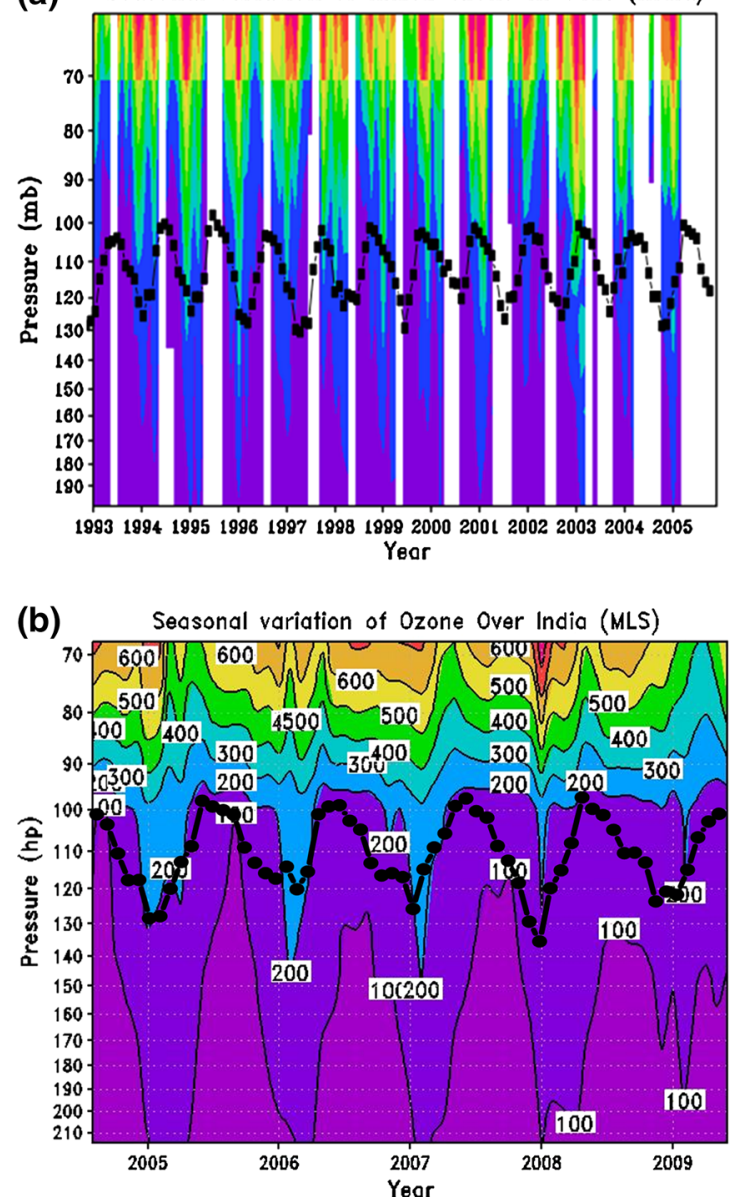

Fig. 5 Vertical distribution of monthly mean ozone vrm obtained from a HALOE for the period 1993-2005. b MLS for the period 2005-2011. Black dotted line over laid shows variation of tropopause pressure. White color indicate non available data

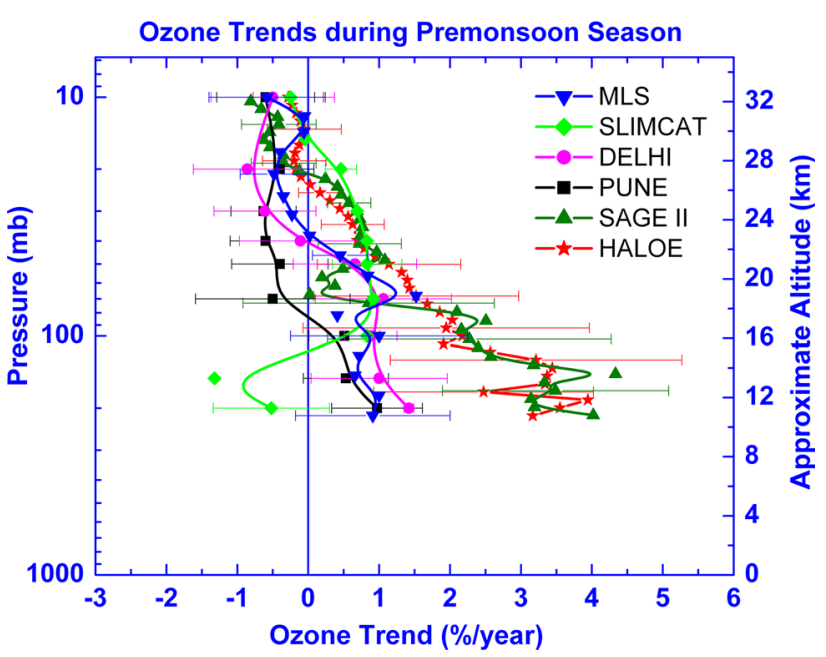

Fig. 6 Vertical variation of trends (\%/year) in ozone during premonsoon season in ozone obtained from HALOE (asterisks), SAGE II (triangles), ozonesonde at Delhi (circles), ozonesonde at Pune (squares), MLS (down triangles), SLIMCAT (diamonds)

over the Indian region. Increasing trends in convective events, lightning activity and $\mathrm{NO}_{x}$ will together contribute to increasing ozone trends in the upper troposphere by enhancing production of ozone (IPCC 2007; Ott et al. 2010; Labrador et al. 2005).

In the lower stratosphere, trends estimated from SAGE II, HALOE, MLS, ozonesonde measurements, and SLIMCAT simulations show that trend values deceases with increase in altitude. Statistically significant increasing trends (0.5-2\%/year) are observed in HALOE, MLS ozonesonde at Delhi, and SLIMCAT data at the altitudes below $60 \mathrm{mb}$. At the altitudes above $60 \mathrm{mb}$ structure of trend profiles vary with data sets. SAGE II, HALOE and 
Table 3 Trend coefficient (\%/year) during pre-monsoon season over the Indian region in ozone measurements from SAGEII 1993-2005), HALOE (1993-2005), MLS (2005-2011), CTM-SLIMCAT
(1993-2005), Ozonesonde at Pune $\left(18^{\circ} \mathrm{N}, 7^{\circ} \mathrm{E}\right)(1993-2005)$, ozonesonde at Delhi $\left(28^{\circ} \mathrm{N}, 7^{\circ} \mathrm{E}\right)(1993-2005)$

\begin{tabular}{|c|c|c|c|c|c|c|}
\hline $\begin{array}{l}\text { Pressure } \\
(\mathrm{hPa})\end{array}$ & $\begin{array}{l}\text { Trend (\%/year) } \\
\text { SAGEII } \\
(1993-2005) \\
\text { pre-monsoon }\end{array}$ & $\begin{array}{l}\text { Trend (\%/year) } \\
\text { HALOE } \\
(1993-2005) \\
\text { pre-monsoon }\end{array}$ & $\begin{array}{l}\text { Trend (\%/year) } \\
\text { MLS } \\
(2005-2011) \\
\text { pre-monsoon }\end{array}$ & $\begin{array}{l}\text { Trend (\%/year) } \\
\text { SLIMCAT } \\
(1993-2005) \\
\text { pre-monsoon }\end{array}$ & $\begin{array}{l}\text { Trend (\%/year) } \\
\text { ozonesonde-Delhi } \\
\left(28^{\circ} \mathrm{N}, 77^{\circ} \mathrm{E}\right) \\
(1993-2005) \\
\text { pre-monsoon }\end{array}$ & $\begin{array}{l}\text { Trend (\%/year) } \\
\text { ozonesonde-Pune } \\
\left(18^{\circ} \mathrm{N}, 73^{\circ} \mathrm{E}\right) \\
(1993-2005) \\
\text { pre-monsoon }\end{array}$ \\
\hline 200 & $3.19 \pm 2.4$ & $3.1 \pm 1.1$ & $0.91 \pm 1.09$ & $-0.52 \pm 0.82$ & $1.42 \pm 0.07$ & $0.97 \pm 0.64$ \\
\hline 150 & $3.33 \pm 1.59$ & $3.3 \pm 1.3$ & $0.66 \pm 0.6$ & $-1.32 \pm 1.5$ & $1 \pm 0.96$ & $0.53 \pm 0.6$ \\
\hline 100 & $2.27 \pm 2$ & $2.17 \pm 2$ & $1 \pm 1.25$ & $0.83 \pm 0.7$ & $0.88 \pm 0.37$ & $0.51 \pm 0.5$ \\
\hline 70 & $0.85 \pm 1.77$ & $1.5 \pm 1.4$ & $1.52 \pm 1.4$ & $0.92 \pm 0.8$ & $1.06 \pm 0.96$ & $-0.5 \pm 1.09$ \\
\hline 50 & $0.48 \pm 0.3$ & $1.13 \pm 1$ & $0.45 \pm 0.39$ & $0.83 \pm 0.49$ & $0.66 \pm 0.87$ & $-0.4 \pm 0.68$ \\
\hline 40 & $0.72 \pm 0.58$ & $0.8 \pm 0.9$ & $0.02 \pm 0.01$ & $0.83 \pm 0.6$ & $-0.11 \pm 0.86$ & $-0.6 \pm 0.5$ \\
\hline 30 & $0.68 \pm 0.33$ & $0.56 \pm 0.3$ & $-0.23 \pm 0.3$ & $0.69 \pm 0.5$ & $-0.61 \pm 0.72$ & $-0.63 \pm 0.46$ \\
\hline 20 & $-0.125 \pm 0.2$ & $-0.17 \pm 0.44$ & $-0.48 \pm 0.45$ & $0.46 \pm 0.22$ & $-0.86 \pm 0.76$ & $-0.4 \pm 0.48$ \\
\hline 10 & $-0.81 \pm 0.5$ & $-0.28 \pm 0.49$ & $-0.58 \pm 0.82$ & $-0.25 \pm 0.22$ & $-0.5 \pm 0.87$ & $-0.6 \pm 0.69$ \\
\hline
\end{tabular}

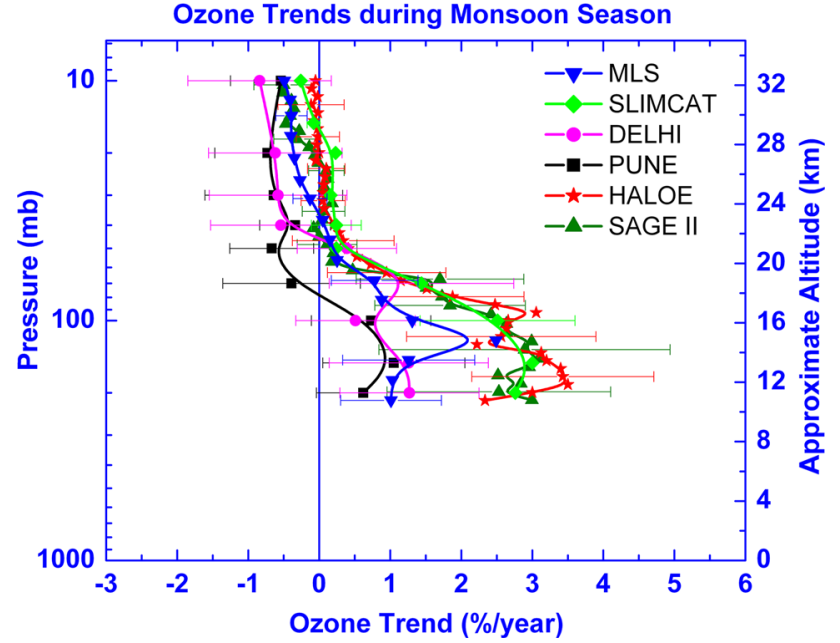

Fig. 7 Vertical variation of trends (\%/year) in ozone during monsoon season in ozone obtained from HALOE (asterisks), SAGE II (triangles), ozonesonde at Delhi (circles), ozonesonde at Pune (squares), MLS (down triangles), SLIMCAT (diamonds). Vertical variation of trends (\%/year) in ozone during Winter season in ozone obtained from HALOE (asterisks), SAGE II (triangles), ozonesonde at Delhi (circles), ozonesonde at Pune (squares), MLS (down triangles), SLIMCAT (diamonds)

SLIMCAT data show increasing trends up to $20 \mathrm{mb}$ while MLS and ozonesonde at Delhi show up to $40 \mathrm{mb}$. Fadnavis and Beig (2006b) also reported increasing ozone trends ( $\sim 0.2 \%$ /year) between 60 and $40 \mathrm{mb}$ over the tropics during pre-monsoon. At Delhi, trend profile also shows increasing trends $(0.6 \pm 0.87-1 \pm 0.96 \%$ /year $)$ between 100 and $40 \mathrm{mb}$ and decreasing trends $(-0.86 \pm 0.76$ to $-0.11 \pm 0.86 \% /$ year) above. Statistically insignificant but positive trends $(0.04 \pm 0.3 \%$ /year) are also observed in tropospheric column data by Kulkarni et al. (2010). At Pune, decreasing trends (statistically significant) are observed in the lower stratosphere $(\sim-0.5 \%$ /year $)$.
Vertical structure of trends in ozone during monsoon season

Always there has been an interest in studying the distribution of ozone trends in the UTLS region during monsoon period as monsoon convection modulates UTLS ozone. Figure 7 show vertical distribution of ozone trends during south-west monsoon season (Trend estimates at standard pressure levels are tabulated in Table 4). In the upper troposphere, HALOE, SAGE II measurements, and SLIMCAT simulations show statistically significant increasing trends varying between 2 and $3.5 \% / y e a r$. Trends estimated from MLS measurements vary between $1 \pm 0.7$ and $2.5 \pm 1.7 \%$ year. Trends obtained from ozonesonde measurements at Delhi and Pune vary between 0.5 and $1.2 \%$ year. Trends obtained from tropospheric column ozone measurements reported by Kulkarni et al. (2010) also show statistically significant increasing trends $\sim 0.3 \pm 0.2 \%$ year at Delhi.

From two dimensional model simulations, Saunois et al. (2008) showed that the ozone precursors emitted at the surface are uplifted by deep convection and then advected in the upper branches of the Hadley cells on both sides of the Inter Tropical Convergence Zone (ITCZ). The $\mathrm{NO}_{x}$ produced by lightning promotes chemical ozone production in the middle and upper troposphere from the oxidation of $\mathrm{CO}$ and VOCs. Ozone is produced in the troposphere by the photochemical oxidation of $\mathrm{CO}$ and hydrocarbons, which is catalyzed by $\mathrm{NO}_{x}$ radicals and hydrogen oxide radicals $\left(\mathrm{HO}_{x}=\mathrm{OH}+\right.$ peroxy $)$. Ghude et al. (2008) observed increasing trends in $\mathrm{NO}_{2}$ over the Indian region during Indian monsoon season. Thus increasing trends in $\mathrm{NO}_{x}$ may result in increasing ozone trends in upper troposphere.

In the lower stratosphere, SAGE II, HALOE, MLS, and SLIMCAT-derived trends decrease rapidly with increase in 
Table 4 Trend coefficient (\%/year) during monsoon season over the Indian region in ozone measurements from SAGEII 1993-2005), HALOE (1993-2005), MLS (2005-2011), CTM-SLIMCAT

\begin{tabular}{|c|c|c|c|c|c|c|}
\hline $\begin{array}{l}\text { Pressure } \\
(\mathrm{hPa})\end{array}$ & $\begin{array}{l}\text { Trend (\%/year) } \\
\text { SAGEII } \\
(1993-2005) \\
\text { monsoon }\end{array}$ & $\begin{array}{l}\text { Trend (\%/year) } \\
\text { HALOE } \\
(1993-2005) \\
\text { monsoon }\end{array}$ & $\begin{array}{l}\text { Trend (\%/year) } \\
\text { MLS } \\
(2005-2011) \\
\text { monsoon }\end{array}$ & $\begin{array}{l}\text { Trend (\%/year) } \\
\text { SLIMCAT } \\
(1993-2005) \\
\text { monsoon }\end{array}$ & $\begin{array}{l}\text { Trend (\%/year) } \\
\text { ozonesonde-Delhi } \\
\left(28^{\circ} \mathrm{N}, 77^{\circ} \mathrm{E}\right) \\
(1993-2005) \\
\text { monsoon }\end{array}$ & $\begin{array}{l}\text { Trend }(\% / \text { year }) \\
\text { ozonesonde-Pune } \\
\left(18^{\circ} \mathrm{N}, 73^{\circ} \mathrm{E}\right) \\
(1993-2005) \\
\text { monsoon }\end{array}$ \\
\hline 200 & $2.52 \pm 1.57$ & $2.33 \pm 1.3$ & $1.01 \pm 0.71$ & $2.76 \pm 1.5$ & $1.27 \pm 0.98$ & $0.62 \pm 0.66$ \\
\hline 150 & $2.95 \pm 2$ & $3.2 \pm 1.5$ & $1.26 \pm 0.93$ & $3 \pm 2.2$ & $1.26 \pm 1.12$ & $1.05 \pm 1$ \\
\hline 100 & $2.63 \pm 1.5$ & $2.6 \pm 1.0$ & $1.31 \pm 1.2$ & $2.51 \pm 1.09$ & $0.51 \pm 0.84$ & $0.73 \pm 0.84$ \\
\hline 70 & $1.51 \pm 1.01$ & $1.1 \pm 0.5$ & $0.78 \pm 0.61$ & $1.44 \pm 1.1$ & $1.44 \pm 1.3$ & $-0.39 \pm 0.96$ \\
\hline 50 & $0.2 \pm 0.3$ & $0.4 \pm 0.6$ & $0.15 \pm 0.2$ & $0.24 \pm 0.8$ & $0.39 \pm 0.7$ & $-0.67 \pm 0.59$ \\
\hline 40 & $-0.08 \pm 0.2$ & $0.2 \pm 0.3$ & $0.05 \pm 0.1$ & $0.24 \pm 0.35$ & $-0.54 \pm 0.99$ & $-0.34 \pm 0.5$ \\
\hline 30 & $0.13 \pm 0.19$ & $0.05 \pm 0.3$ & $-0.13 \pm 0.24$ & $0.16 \pm 0.3$ & $-0.58 \pm 0.97$ & $-0.64 \pm 0.97$ \\
\hline 20 & $-0.06 \pm 0.21$ & $-0.05 \pm 0.4$ & $-0.35 \pm 0.4$ & $0.23 \pm 0.7$ & $-0.62 \pm 0.94$ & $-0.73 \pm 0.74$ \\
\hline 10 & $-0.5 \pm 0.42$ & $-0.052 \pm 0.5$ & $-0.49 \pm 0.6$ & $-0.26 \pm 0.09$ & $-0.84 \pm 1.01$ & $-0.54 \pm 0.71$ \\
\hline
\end{tabular}

(1993-2005), Ozonesonde at Pune $\left(18^{\circ} \mathrm{N}, 7^{\circ} \mathrm{E}\right)$ (1993-2005), ozonesonde at Delhi $\left(28^{\circ} \mathrm{N}, 7^{\circ} \mathrm{E}\right)(1993-2005)$ altitude. Statistically significant but increasing trends are observed between 100 and $70 \mathrm{mb}$. At the altitudes above $70 \mathrm{mb}$, statistically insignificant nearly zero trends are observed in SAGE II, HALOE, and MLS data.

Recently from satellite based observations Randel et al. (2010) confirmed that transport through the Asian Summer monsoon can potentially penetrate deep into the stratosphere. During Indian Summer monsoon water vapor is transported into the lower stratosphere due to deep convection. Increase in trends in extreme rain events through strong monsoon convection (Goswami et al. 2006) increases moisture supply in the lower stratosphere. Since water vapor acts as an in situ source of odd hydrogen in the stratosphere, the water vapor perturbations affect the gas-phase chemistry of hydrogen oxides. An additional water vapor amount of +1 ppmv results in increase of $\mathrm{OH}$ 5-10 \%. Coupling processes between $\mathrm{HO}_{x}$ and $\mathrm{NO}_{x} / \mathrm{ClO}_{x}$ affect the ozone destruction by other catalytic reaction cycles (Stenke and Grewe 2004; Tian et al. 2009; Fleming et al. 2011). This may be the reason for observed almost no trends in the lower stratosphere. Observed ozone trends $(-0.3$ to $-0.8 \% /$ year $)$ at Delhi and Pune are also lesser than other seasons.

\section{Vertical structure of trends in ozone during post-monsoon season}

Figure 8 shows the vertical distribution of ozone trends from HALOE, SAGE II, MLS, SLIMCAT, and ozonesonde at Delhi and Pune data during post monsoon season (October-November) (Trend estimates at standard pressure levels are tabulated in Table 5). In the upper troposphere, statistically significant increasing trends are observed in HALOE, SLIMCAT data, and ozonesonde measurements at Delhi. Kulkarni et al. (2010) also reported statistically

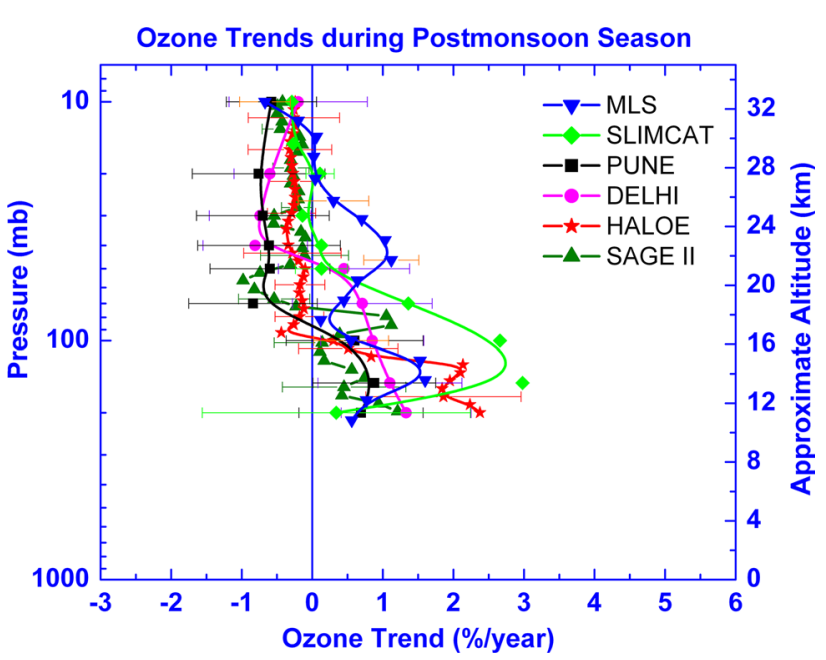

Fig. 8 Vertical variation of trends (\%/year) in ozone during posetmonsoon season in ozone obtained from HALOE (asterisks), SAGE II (triangles), ozonesonde at Delhi (circles), ozonesonde at Pune (squares), MLS (down triangles), SLIMCAT (diamonds)

significant increasing trends $(0.32 \pm 0.3-0.786 \pm 0.3 \% /$ year) in tropospheric column data over the Indian inland cities. However, statistically insignificant but positive trends are observed in SAGE II data, MLS, and ozonesonde measurements at Pune. The reason may be related to less number of data points as post-monsoon seasons consist of only 2 months (October-November), which reduces the statistical robustness of the time series. During post-monsoon season biomass burning leads to production of ozone precursors. During this season, withdrawal of monsoon is accompanied by thunderstorm and lightning activity, which contribute to ozone production via $\mathrm{NO}_{x}$ (Ott et al. 2010). During this season, large numbers of tropical cyclones form in the Indian Ocean, which are increasing in number 
Table 5 Trend coefficient (\%/year) during post-monsoon season over the Indian region in ozone measurements from SAGEII 1993-2005), HALOE (1993-2005), MLS (2005-2011), CTM-SLIMCAT
(1993-2005), Ozonesonde at Pune $\left(18^{\circ} \mathrm{N}, 7^{\circ} \mathrm{E}\right)(1993-2005)$, ozonesonde at Delhi $\left(28^{\circ} \mathrm{N}, 7^{\circ} \mathrm{E}\right)(1993-2005)$

\begin{tabular}{|c|c|c|c|c|c|c|}
\hline $\begin{array}{l}\text { Pressure } \\
(\mathrm{hPa})\end{array}$ & $\begin{array}{l}\text { Trend (\%/year) } \\
\text { SAGEII } \\
(1993-2005) \\
\text { post-monsoon }\end{array}$ & $\begin{array}{l}\text { Trend (\%/year) } \\
\text { HALOE } \\
(1993-2005) \\
\text { post-monsoon }\end{array}$ & $\begin{array}{l}\text { Trend (\%/year) } \\
\text { MLS } \\
(2005-2011) \\
\text { post-monsoon }\end{array}$ & $\begin{array}{l}\text { Trend (\%/year) } \\
\text { SLIMCAT } \\
(1993-2005) \\
\text { post-monsoon }\end{array}$ & $\begin{array}{l}\text { Trend (\%/year) } \\
\text { ozonesonde-Delhi } \\
\left(28^{\circ} \mathrm{N}, 77^{\circ} \mathrm{E}\right) \\
(1993-2005) \\
\text { post-monsoon }\end{array}$ & $\begin{array}{l}\text { Trend (\%/year) } \\
\text { ozonesonde-Pune } \\
\left.18^{\circ} \mathrm{N}, 73^{\circ} \mathrm{E}\right) \\
(1993-2005) \\
\text { post-monsoon }\end{array}$ \\
\hline 200 & $1.21 \pm 1.5$ & $2.37 \pm 1.2$ & $0.56 \pm 0.5$ & $0.34 \pm 0.19$ & $1.33 \pm 0.92$ & $0.69 \pm 0.88$ \\
\hline 150 & $0.45 \pm 0.87$ & $1.95 \pm 1.1$ & $1.6 \pm 1.3$ & $2.98 \pm 1.2$ & $1.1 \pm 1.02$ & $0.88 \pm 0.87$ \\
\hline 100 & $0.14 \pm 0.68$ & $0.3 \pm 0.6$ & $0.55 \pm 0.53$ & $2.66 \pm 1.4$ & $0.85 \pm 0.73$ & $0.6 \pm 0.57$ \\
\hline 70 & $-0.54 \pm 0.5$ & $-0.14 \pm 0.3$ & $0.45 \pm 0.5$ & $1.36 \pm 0.37$ & $0.71 \pm 0.99$ & $-0.84 \pm 0.61$ \\
\hline 50 & $-0.31 \pm 0.5$ & $-0.1 \pm 0.6$ & $1.12 \pm 0.39$ & $0.13 \pm 0.2$ & $0.45 \pm 0.93$ & $-0.6 \pm 0.45$ \\
\hline 40 & $-0.14 \pm 0.6$ & $-0.33 \pm 0.8$ & $1.03 \pm 0.45$ & $0.13 \pm 0.22$ & $-0.81 \pm 0.74$ & $-0.61 \pm 0.51$ \\
\hline 30 & $-0.54 \pm 0.6$ & $-0.34 \pm 0.4$ & $0.7 \pm 0.6$ & $-0.14 \pm 0.15$ & $-0.74 \pm 0.72$ & $-0.7 \pm 0.5$ \\
\hline 20 & $-0.26 \pm 0.15$ & $-0.25 \pm 0.37$ & $0.04 \pm 0.3$ & $0.11 \pm 0.2$ & $-0.6 \pm 0.51$ & $-0.76 \pm 0.94$ \\
\hline 10 & $-0.42 \pm 0.3$ & $-0.26 \pm 0.64$ & $-0.67 \pm 0.36$ & $-0.29 \pm 0.20$ & $-0.2 \pm 0.98$ & $-0.58 \pm 0.64$ \\
\hline
\end{tabular}

(Webster et al. 2005; Yu and Wang 2009). Increase in ozone precursors due to enhanced anthropogenic activates over India and increasing convective activity transports more pollutants to upper troposphere. Also, increasing trends are observed in $\mathrm{NO}_{x}$ produced due to lightning (Lal and Pawar 2011). Increasing trends in ozone precursors and lightning produced $\mathrm{NO}_{x}$ in the upper troposphere may contribute to the observed increasing trends in ozone. Trends are significant at Delhi (0.5-1.3\%/year) during this period, which may be due to occurrence of enhanced biomass burning activity in the North India. Also region around Delhi corridor is densely populated and highly industrialized hence ozone production in general is high.

In the lower stratosphere, trends obtained from SAGE II and HALOE, and ozonesonde measurements at Pune data are statistically insignificant as number of data points are less. However, statistically significant increasing trends are obtained from MLS and ozonesonde measurements at Delhi data between 100 and $30 \mathrm{mb}$. These increasing trends may be the effect of tropospheric convection.

\section{Conclusion}

Regression analysis of ozone measurements from SAGE II, HALOE, and SLIMCAT simulations (1993-2005), MLS (2005-2011) over the Indian region and from ozonesonde at Delhi and Pune during the period 1993-2005 exhibit increasing annual trends (0.5 and $2 \%$ /year) in the upper troposphere. In the lower stratosphere, estimated trends are increasing between 100 and $30 \mathrm{mb}$ and are decreasing between 30 and $10 \mathrm{mb}$ as observed in satellite data sets and SLIMCAT simulations. The observed contrasting ozone trend profiles might be partially responsible for insignificant long-term trends in the tropical total column ozone.
During winter, significant increasing trends are observed near tropopause in all the data sets (except ozonesonde measurements at Pune). Increasing trends in subtropical upper troposphere may be due to downward transport of ozone during stratospheric intrusion during Winterpre-monsoon season (as evident in HALOE and MLS observations). Increasing ozone trends are also observed during pre-monsoon and post-monsoon seasons in the upper troposphere. This may be due to number of factors such high biomass burning activity leading to increasing ozone precursors. Transport of these boundary layer ozone precursors to upper troposphere. Also increasing trends in lightning flashes contribute to increase in upper tropospheric ozone (via $\mathrm{NO}_{x}$ ). During these seasons, intense convective systems in the troposphere may have their tops crossing the tropopause and consequently pump ozone precursors in lower stratosphere. This may be attributing to observed increasing ozone trends in the lower stratosphere (100-30 mb).

During monsoon season, increasing trends of 0.5-3.5 \%/ year are observed in the upper troposphere in all the data sets. In the lower stratosphere, increasing trends extends up to $50 \mathrm{mb}$ (except at Pune). Statistically insignificant but decreasing trends are observed at the altitudes above $50 \mathrm{mb}$. Ozone precursors emitted at the surface are uplifted by deep monsoon convection and then advected into the upper troposphere. Deep convection in the tropics flushes the upper troposphere, brings in fresh sources of $\mathrm{NO}$ and $\mathrm{HO}_{x}$ reservoirs. Increasing ozone trends may be due to increase in $\mathrm{NO}_{x}$ Transport through the Asian Summer monsoon can potentially penetrate deep into the stratosphere. During Indian Summer monsoon UTLS moisture is higher and as water vapor acts as an in situ source of odd hydrogen, the water vapor perturbations can influence the gas-phase chemistry of hydrogen oxides. Coupling processes between $\mathrm{HO}_{x}$ and $\mathrm{NO}_{x} / \mathrm{ClO}_{x}$ affect the ozone destruction by other catalytic 
reaction cycles. This may be the reason for almost no trends observed during monsoon season in the lower stratosphere.

Acknowledgments We thank NASA and NOAA for the SAGE II, HALOE and MLS data sets. We also acknowledge use of the ECMWF data which was obtained via the BADC.

\section{References}

Baray JL, Ancellet G, Randriambelo T, Baldy S (1999) Tropical cyclone Marlene and stratosphere-troposphere exchange. J Geophys Res 104(D11):13953-13970. doi:10.1029/1999JD900028

Borchi F, Pommereau JP (2007) Evaluation of ozonesondes, HALOE, SAGE II and III, Odin-OSIRIS and -SMR, and ENVISATGOMOS, -SCIAMACHY and -MIPAS ozone profiles in the tropics from SAOZ long duration balloon measurements in 2003 and 2004. Atmos Chem Phys 7:2671-2690

Braesicke P, Smith OJ, Telford P, Pyle JA (2011) Ozone concentration changes in the Asian summer monsoon anticyclone and lower stratospheric water vapour: an idealized model study. Geophys Res Lett 38:L03810. doi:10.1029/2010GL046228

Chipperfield MP (1999) Multiannual simulations with a three-dimensional chemical transport model. J Geophys Res 104:1781-1805

Chipperfield MP (2006) New version of the TOMCAT/SLIMCAT offline chemical transport model: intercomparison of stratospheric tracer experiments. Q J Royal Meteorol Soc 132(617):1179-1203

Cunnold DM, Chu WP, Barnes RA, McCormick MP, Veiga RE (1989) Validation of SAGE II ozone measurements. J Geophys Res 94:8447-8460

Das SS (2009) A new perspective on MST radar observations of stratospheric intrusions into-troposphere associated with tropical cyclone. Geophys Res Lett 36:L15821. doi:10.1029/2009GL039184

Das SS, Sijikumar S, Uma KN (2011) Further investigation on stratospheric air intrusion into the troposphere during the episode of tropical cyclone: numerical simulation and MST radar observations. Atmos Res 101:928-937

Dee DP, Uppala SM, Simmons AJ, Berrisford P, Poli P, Kobayashi S, Andrae U, Balmaseda MA, Balsamo G, Bauer P, Bechtold P, Beljaars ACM, van de Berg L, Bidlot J, Bormann N, Delsol C, Dragani R, Fuentes M, Geer AJ, Haimberger L, Healy SB, Hersbach H, Hólm EV, Isaksen L, Kållberg P, Köhler M, Matricardi M, McNally AP, Monge-Sanz BM, Morcrette J-J, Park B-K, Peubey C, de Rosnay P, Tavolato C, Thépaut J-N, Vitart F (2011) The ERA-Interim reanalysis: configuration and performance of the data assimilation system. Q J Royal Meteorol Soc 137:553-597. doi:10.1002/qj.828

Dhomse S, Weber M, Wohltmann I, Rex M, Burrows J (2006) On the possible causes of recent increases in northern hemispheric total ozone from a statistical analysis of satellite data from 1979 to 2003. Atmos Chem Phys 6:1165-1180

Dhomse S, Chipperfield MP, Feng W, Haigh JD (2011) Solar response in tropical stratospheric ozone: a 3-D chemical transport model study using ERA reanalyses. Atmos Phys Chem Discuss 11:13975-14001

Eyring V, Cionni I, Lamarque JF, Akiyoshi H, Bodeker GE, CharltonPerez AJ, Frith SM, Gettelman A, Kinnison DE, Nakamura T, Oman LD, Pawson S, Yamashita Y (2010) Sensitivity of 21st century stratospheric ozone to greenhouse gas scenarios. Geophys Res Lett 37:16

Fadnavis S, Beig G (2006a) Decadal solar effects on temperature and ozone in the tropical stratosphere. Ann Geophys 24:2091-2103

Fadnavis S, Beig G (2006b) Seasonal variation of trend in temperature and ozone over the tropical stratosphere in the Northern Hemisphere. J Atoms Sol Terri Phys 68:1952-1961
Fadnavis S, Chakraborty T, Beig G (2010) Seasonal stratospheric intrusion of ozone in the upper troposphere over India. Ann Geophys 28:2149-2159

Fadnavis S, Buchunde P, Ghude SD, Kulkarni SH, Beig G (2011) Evidence of seasonal enhancement of $\mathrm{CO}$ in the upper troposphere over India. Int J Rem Sens 32(22):7441-7452

Fleming EL, Jackman CH, Stolarski RS, Douglass AR (2011) A model study of the impact of source gas changes on the stratosphere for 1850-2100. Atmos Chem Phys

Forster PMdeF, Shine KP (1997) Radiative forcing and temperature trends from stratospheric ozone changes. J Geophys Res 102: 10841-10857

Forster PM, Bodeker G, Schofield R, Solomon S, Thompson D (2007) Effects of ozone cooling in the tropical lower stratosphere and upper troposphere. Geophys Res Lett 34(11):8515-8541. doi: 10.1029/2007GL031994

Froidevaux L, Jiang YB, Lambert A, Livesey NJ, Read WG, Waters JW, Browell EV, Hair JW, Avery MA, McGee TJ, Twigg LW, Sumnicht GK, Jucks KW, Margitan JJ, Sen B, Stachnik RA, Toon GC, Bernath PF, Boone CD, Walker KA, Filipiak MJ, Harwood RS, Fuller RA, Manney GL, Schwartz MJ, Daffer WH, Drouin BJ, Cofield RE, Cuddy DT, Jarnot RF, Knosp BW, Perun VS, Snyder WV, Stek PC, Thurstans RP, Wagner PA (2008) Validation of Aura Microwave Limb Sounder stratospheric ozone measurements. J Geophys Res 113:D15S20. doi:10.10 29/2007JD008771

Galanter M, Levy H II, Carmichael GR (2000) Impacts of biomass burning on tropospheric CO, NOx, and O3. J Geophys Res 105:6633-6653

Ganguly ND (2009) Variation in atmospheric ozone concentration following strong earthquakes. Int J Rem Sen 30(2):349-356

Ghude SD, Fadnavis S, Beig G, Polade SD, der Van RJA (2008) Detection of surface emission hot spots, trends, and seasonal cycle from satellite-retrieved $\mathrm{NO}_{2}$ over India. J Geophys Res 113:D20305. doi:10.1029/2007JD009615

Ghude SD, Kulkarni SH, Kulkarni PS, Kanawade VP, Fadnavis S, Pokhrel S, Jena C, Beig G, Bortoli D (2011) Anomalous low tropospheric column ozone over Eastern India during the severe drought event of monsoon 2002: a case study. Environ Sci Poll Res 18:1442-1455. doi:10.1007/s11356-011-0506-4

Goswami BN, Venugopal V, Sengupta D, Madhusoodanan MS, Prince Xavier K (2006) Increasing trend of extreme rain events over India in a warming environment. Science 314:1442-1445

Harris NRP, Ancellet G, Bishop L, Hofmann DJ, Kerr JB, McPeters RD, Prendez M, Randel WJ, Staehelin J, Subbaraya BH, VolzThomas A, Zawodny J, Zerefos CS (1997) Trends in stratospheric and free tropospheric ozone. J Geophys Res 102: $1571-1590$

Intergovernmental Panel on Climate Change, Climate Change (IPCC) (2001) The Scientific Basis-Contribution of Working Group I to the Third Assessment Report of the Intergovernmental Panel on Climate Change. In: Houghton JT, Ding Y, Griggs DJ, Noguer M, van der Linden PJ, Dai X, Maskell K, Johnson CA (eds). Cambridge Univ Press, New York

Intergovernmental Panel on Climate Change, Climate Change (IPCC) (2007) The Physical Science Basis, Summary for Policymakers-Contribution of Working Group I to the Fourth Assessment Report of the Intergovernmental Panel on Climate Change. Cambridge Univ Press New York

Krishnamurti TN, Chakraborty A, Martin A, Lau WK, Kim KM, Sud Y, Walker G (2009) Impact of Arabian Sea Pollution on the Bay of Bengal winter monsoon rains. J Geophys Res 114:D06213. doi:10.1029/2008JD010679

Kulkarni PS, Ghude SD, Bortoli D (2010) Tropospheric ozone (TOR) trend over three major inland Indian cities: Delhi, Hyderabad and Bangalore. Ann Geophys 28:1879-1885 
Kunze M, Braesicke P, Langematz U, Stiller G, Bekki S, Brühl C, Chipperfield M, Dameris M, Garcia R, Giorgetta M (2010) Influences of the Indian Summer Monsoon on water vapor and ozone concentrations in the UTLS as simulated by chemistry-climate models. J Clim 23:3525-3544. doi:10.1175/2010JCLI3280.1

Labrador LJ, von Kuhlmann R, Lawrence MG (2005) The effects of lightning-produced NOx and its vertical distribution on atmospheric chemistry: sensitivity simulations with MATCHMPIC. Atmos Chem Phys 5:1815-1834

Lal DM, Pawar SD (2011) Effect of urbanization on lightning over four metropolitan cities of India. Atmos Environ 45:191-196

Lamarque JF, Solomon S (2010) Impact of changes in climate and halocarbons on recent lower stratospheric ozone and temperature trends. J Clim 23:2599-2611. doi:10.1175/2010JCLI3179.1

Livesey NJ, Van Snyder W, Read WG, Wagner PA (2006) Retrieval algorithms for the EOS Microwave Limb Sounder (MLS). IEEE Trans Geosci Remote Sens 44(5):1144-1155

Logan JA, Megretskaia IA, Miller AJ, Tiao GC, Choi D, Zhang L, Stolarski RS, Labow GJ, Hollandsworth SM, Bodeker GE, Claude H, De Muer D, Kerr JB, Tarasick DW, Oltmans SJ, Johnson B, Schmidlin F, Staehelin J, Viatte P, Uchino O (1999) Trends in vertical distribution of ozone: a comparison of two analyses of ozonesonde data. J Geophys Res 104:26373-26399

Neter J, Wasserman W, Kunter MH (1985) Applied linear statistical models, 2nd edn. RD Irwin, Homewood

Nishanth T, Satheesh KMK (2011) Increasing trends of tropospheric ozone and $\mathrm{NO}_{2}$ at the prominent hot spots along the coastal belt of the Arabian Sea in Indian subcontinent. Int $\mathbf{J}$ Environ Sci 1(5):860-870

Oltmans SJ, Lefohn AS, Scheel HE, Harris JM, Levy H II, Galbally IE, Brunke E-G, Meyer CP, Lathrop JA, Johnson BJ, Shadwick DS, Cuevas E, Schmidlin FJ, Tarasick DW, Claude H, Kerr JB, Uchino O, Mohnen V (1998) Trends of ozone in the troposphere. Geophys Res Lett 25:139-142

Ott LE, Pickering KE, Stenchikov GL, Allen DJ, DeCaria AJ, Ridley B, Lin RF, Lang S, Tao WK (2010) Production of lightning $\mathrm{NO}_{x}$ and its vertical distribution calculated from three-dimensional cloud-scale chemical transport model simulations. J Geophys Res 115:D04301. doi:10.1029/2009JD011880

Pan L, Solomon S, Randel WJ, Lamarque JF, Hess P, Gille JC, Chiou EW, McCormick P (1997) Hemispheric asymmetry and seasonal variations of the lowermost stratospheric water vapor and ozone derived from SAGE II data. J Geophys Res 102(D23):28177-28184

Park M, Randel WJ, Emmons LK, Livesey NJ (2009) Transport pathways of carbon monoxide in the Asian summer monsoon diagnosed from Model of Ozone and Related Tracers (MOZART). J Geophys Res 114:D08303

Phadnis MJ, Levy H II, Moxim WJ (2002) On the evolution of pollution from South and Southeast Asia during the winterspring monsoon. J Geophys Res 107(D24):4790. doi:10.1029/2002JD 002190

Randel WJ, Cobb JB (1994) Coherent variations of monthly mean total ozone and lower stratospheric temperature. J Geophys Res 99:5433-5477

Randel WJ, Thompson AM (2011) Interannual variability and trends in tropical ozone derived from SAGE II satellite data and SHADOZ ozonesondes. J Geophys Res 116:D07303. doi:10.10 29/2010JD015195

Randel WJ, Wu F (2007) A stratospheric ozone profile data set for 1979-2005: variability, trends, and comparisons with column ozone data. J Geophys Res 112:D06313. doi:10.1029/2006JD007339

Randel WJ, Stolarski RS, Cunnold DM, Logan JA, Newchurch MJ, Zawodny JM (1999) Trends in the vertical distribution of ozone. Science 285:1689-1692

Randel WJ, Park M, Emmons L, Kinnison D, Bernath P, Walker KA, Boone C, Pumphrey H (2010) Asian monsoon transport of pollution to the stratosphere. Science 328(5978):611-613. doi: $10.1126 /$ science. 1182274

Russell JM, Gordley LL, Park JH, Drayson SR, Tuck AF, Harries JE, Cicerone RJ, Crutzen PJ, Frederick JE (1993) The halogen occultation experiment. J Geophys Res 89:5115-5124

Saraf N, Beig G (2004) Long term trends in tropospheric ozone over the Indian tropical region. Geophys Res Lett 31:L05101. doi: 10.1029/2003GL018516

Saunois M, Mari C, Thouret V (2008) An idealized two dimensional approach to study the impact of the West African monsoon on the meridional gradient of tropospheric ozone. J Geophys Res 113:D07306. doi:10.1029/2007JD008707

Shreedharan CR (1968) An Indian electrochemical ozonesonde. J Phys E Sci Instrum 2:995-997

Sigmond M, Meloen J, Siegmund PC (2000) Stratosphere-troposphere exchange in an extra tropical cyclone, calculated with a Lagrangian method. Ann Geophysicae 18:573-582

Smit HGJ, Straeter W (1996) JOSIE: The 1996 WMO international intercomparison of ozonesonde under quasi flight conditions in the environmental simulation chamber at Julich. In: Proceedings of XVIII Quadrennial Ozone Symposium. In: Bojkov R, Visconti G Int Ozone Comm, Int Assoc Meteorol Atmos Sci, Toronto

Staehelin J, Harris NRP, Appenzeller C, Eberhard J (2001) Ozone trends: a review. Rev Geophys 39:231-290

Stenke A, Grewe V (2004) Simulation of stratospheric water vapor trends: impact on stratospheric ozone chemistry. Atmos Chem Phys Discuss 4:6559-6602

Terao Y, Logan JA (2007) Consistency of time series and trends of stratospheric ozone as seen by ozonesondes, SAGE II, HALOE, and SBUV(/2). J Geophys Res 112:D06310. doi:10.1029/2006 JD007667

Tian WS, Chipperfield MP, Lu DR (2009) Impact of increasing stratospheric water vapour on ozone depletion and temperature change. Adv Atmos Sci 26(3):432-437. doi:10.1007/s00376009-0423-3

Wang PH, McCormick MP, Poole LR, Chu WP, Yue GK, Kent GS, Skeens KM (1994) Tropical high cloud characteristics derived from SAGE II extinction measurements. Atmos Res 34:53-83

Wang PH, Kent GS, Yue GK, Powell KA, Poole LR, Steele SM (1998) Simulation of SAGE II tropical particulate extinctions near the tropopause using a simple microphysical model. OSA Tech Dig Cirrus, pp 78-80

Wang PH, Minnis P, Wielicki BA, Wong T, Vann LB (2002) Satellite observations of long-term changes in tropical cloud and outgoing longwave radiation from 1985 to 1998. Geophys Res Lett 29:1397. doi:10.1029/2001GL01426.4

Wang Y, Konopka P, Liu Y, Chen H, Müller R, Plöger F, Riese M, Cai Z, Lü D (2012) Tropospheric ozone trend over Beijing from 2002-2010: ozonesonde measurements and modeling analysis. Atmos Chem Phys 12:8389-8399. doi:10.5194/acp-12-8389-2012

Waters JW et al (2006) The Earth Observing System Microwave Limb Sounder (EOS MLS) on the Aura Satellite. IEEE Trans Geosci Remote Sens 44:1075-1092

Webster PJ, Holland GJ, Curry JA, Chang HR (2005) Changes in tropical cyclone number, duration, and intensity in a warming environment. Science 309:1844-1846

WMO/UNEP, Scientific Assessment of Ozone Depletion (2010) Prepared by the scientific assessment panel of the Montreal protocol on substances that deplete the ozone layer

World Meteorological Organization (WMO) (1994) Third WMO inter-comparison of the ozonesonde used in the Global Ozone Observing System (Vanscoy Canada 13-24 May 1991), Global Atmos Watch Rep 27, Geneva Switzerland

Yu J, Wang Y (2009) Response of tropical cyclone potential intensity over the north Indian Ocean to global warming. Geophys Res Lett 36:L03709. doi:10.1029/2008GL03674 